\title{
INDUCTION AND SYNCHRONIZATION OF ESTRUS IN DAIRY COWS USING A SINGLE INJECTION OF PGF2 $\alpha$ AND GnRH
}

\author{
MUJIĆ E*, JOTANOVIĆ STOJA**, NEDIĆ $D^{\star * *}$, TEŠIĆ $M^{* * *}$, ŠAHINOVIĆ R*, VEKIĆ M** \\ and VILIĆ H* \\ *University of Bihać, Biotechnical Faculty, Bihać, Bosnia and Herzegovina; \\ **University of Banja Luka, Faculty of Agriculture, Banja Luka, Bosnia and Herzegovina \\ ***University of Belgrade, Faculty of Veterinary Medicine, Belgrade, Serbia \\ (Received 9th May 2012)
}

The aim of this study was to examine the effects of treatment with a single injection of GnRH and PGF2 $\alpha$ on estrous response, fertility and service period. A total of 120 lactating Simmental cows were divided into four groups of 30 cows each: group PGF2 $\alpha 40$ was treated on the $40^{\text {th }}$ day post partum with a single injection of $2 \mathrm{~mL}$ prostaglandin analogue (Estrumate), group PGF2 $\alpha 50$ was treated in the same way on the $50^{\text {th }}$ day, group $\mathrm{GnRH}$ was treated on the $40^{\text {th }}$ day post partum with a single injection of $2 \mathrm{~mL} \mathrm{GnRH}$ analogue (Receptal), and the fourth group (control) was not hormonally treated. Fertility of cows was not significantly different $(p>0.05)$. The difference in the estrous response and service-period between the control group and experimental groups was statistically significant $(p<0.01)$.

Key words: cows, fertility, GnRH, induction, PGF2 $\alpha$,

\section{INTRODUCTION}

There is a growing trend towards decreased reproductive efficiency in dairy cattle, especially high-yielding dairy cows. Intensive selection for milk production has had a negative effect on the reproductive performance, mainly due to clinical problems in the postpartum period, poor expression of external estrous signs, and defective oocytes and embryos (Nakada, 2006; Dobson et al., 2007). Also, a negative energy balance in early postpartum (Diskin et al., 2003), organizational failure to detect estrus in a timely manner (Mayne et al., 2002; Groehn and RajalaSchultz, 2000), and an inadequate insemination technique (García-Ispierto et al., 2007) can lead to unsatisfactory reproductive performance on dairy farms.

In order to improve the reproductive efficiency of dairy cows, a number of different hormonal protocols are used to systematically affect their physiological and reproductive processes. Of greatest importance in commercial production is the induction of synchronized estrus in the postpartum period, because it helps to establish a synchronized ovarian function. For this purpose, one can use luteolitics, primarily prostaglandin F2 $\alpha$ (PGF2 $\alpha$ ) or its analogues in combination 
with gonadotropin-releasing hormone $(\mathrm{GnRH})$ or its analogues according to a specified schedule of application of each hormone. In this way, luteal regression is induced in a targeted manner by means of prostaglandins (Lauderdale et al., 1974) and ovulation of the dominant follicle is induced by using $\mathrm{GnRH}$ (Britt et al., 1974).

The dairy sector in Bosnia and Herzegovina is largely dominated by milk producers who raise dual purpose Simmental cattle. Although the production is mainly focused on milk production, the profits earned from the sale of calves significantly affect the total cost of production. In this sense, the service period or intercalving interval is not only a reproductive, but also a very important production parameter that directly affects the economic results of dairy farms. Although improved reproductive performance is known to simultaneously improve the entire production, milk producers are relatively unlikely to use conventional hormonal treatments to induce and synchronize estrus, mainly due to insufficient budgets. Taking into account the above facts, our research was based on the hypothesis that a treatment with only one injection of PGF2 $\alpha$ or $\mathrm{GnRH}$ analogues in the final stage of puerperium will result in better reproductive performance, especially estrous response. At the same time, induction and synchronization will be less labor intensive and more financially acceptable for the average milk producer, compared to conventional hormonal protocols.

The aim of this study was to examine the effect of different methods of estrous induction and synchronization on estrous response, pregnancy rate and duration of service period in lactating Simmental cows.

\section{MATERIALS AND METHODS}

The research was conducted on a dairy farm in the vicinity of Bihac in Bosnia and Herzegovina. A total of 120 Simmental cows aged 3 to 6 years, with average annual milk production of $7000 \mathrm{~kg}$, were used in this research. All cows were kept in the free stall system with seasonal access to pasture in the period from May to September.

The cows were divided into four equal groups of 30 animals each: in the PGF2 $\alpha 40$ group were cows treated with a single injection of $2 \mathrm{~mL}$ i.m. PGF2 $\alpha$ analogue (cloprostenol sodium, Estrumate, Schering-Plough) on the $40^{\text {th }}$ day postpartum, in the PGF2 $\alpha 50$ group were cows treated in the same way on the $50^{\text {th }}$ day postpartum, in the GnRG group were cows treated with $2 \mathrm{~mL}$ i.m. of $\mathrm{GnRH}$ analogue (buserelin acetate, Receptal, Intervet) on the $40^{\text {th }}$ day postpartum, and in the control group were cows that were not hormonally treated. All cows were kept under the same nutrition, nursing and health care conditions.

A complete gynecological examination was performed before hormonal treatment in order to determine the involutional processes of the uterus and ovarian functional activity. All treated cows were in the luteal phase of the estrous cycle. Estrous detection was carried out by observation for external signs of estrus.

Insemination was performed by usual bimanual method after expression of external signs of estrus. Insemination of cows in the control group was performed 
Acta Veterinaria (Beograd), Vol. 62, No. 5-6, 591-598, 2012.

Mujić $\mathrm{E}$ et al.: Induction and synchronization of estrus in

dairy cows using a single injection of PGF2 $\alpha$ and GnRH

at the first spontaneous estrus which appeared after the $40^{\text {th }}$ day postpartum. All cows were inseminated with semen from the same bull. Diagnosis of pregnancy was performed by rectal palpation 11-12 weeks after insemination.

Statistical analysis of the obtained data was performed using standard methods of descriptive analysis. Chi-square test was used to compare the value of estrous response and pregnancy rate, and Student's t-test to compare the values of the interval treatment - estrous response and service period between the groups (Petrie and Watson, 2006). The significance of the difference was based on the possibility $p<0.05$, unless specified otherwise.

\section{RESULTS}

The distribution of estrous response by days after hormonal treatment and the average duration of the interval from treatment to estrus response are shown in Table 1.

Table 1. Distribution of estrous response and average duration of the interval from treatment to estrus

\begin{tabular}{|c|c|c|c|c|c|c|c|c|}
\hline \multirow{3}{*}{$\begin{array}{l}\text { Parameters } \\
\text { Days of estrous } \\
\text { response }\end{array}$} & \multicolumn{8}{|c|}{ Groups } \\
\hline & \multicolumn{2}{|c|}{$\mathrm{PGF}_{2 \alpha} 40$} & \multicolumn{2}{|c|}{$\mathrm{PGF}_{2 \alpha} 50$} & \multicolumn{2}{|c|}{$\mathrm{GnRH}$} & \multicolumn{2}{|c|}{ Control } \\
\hline & $\mathrm{n}$ & $\%$ & $\mathrm{n}$ & $\%$ & $\mathrm{n}$ & $\%$ & $\mathrm{n}$ & $\%$ \\
\hline $1-3$ & 10 & 33.34 & 12 & 40.00 & 11 & 36.67 & - & - \\
\hline 4-6 & 12 & 40.00 & 101 & 33.34 & 8 & 26.67 & 5 & 16.66 \\
\hline $7-9$ & 1 & 3.33 & 11 & 3.33 & 7 & 23.33 & 4 & 13.33 \\
\hline$\geq 10$ & 1 & 3.34 & 3 & 10.00 & 2 & 6.67 & 10 & 33.33 \\
\hline Total & 24 & 80.00 & 26 & 86.67 & 28 & 93.34 & 19 & 63.34 \\
\hline $\begin{array}{l}\text { Interval treatment - } \\
\text { estrous response } \\
\text { (mean } \pm \text { stand. error) }\end{array}$ & \multicolumn{2}{|c|}{$3.92 \pm 0.49^{b}$} & \multicolumn{2}{|c|}{$4.69 \pm 0.68^{b}$} & \multicolumn{2}{|c|}{$5.14 \pm 0.76^{b}$} & \multicolumn{2}{|c|}{$11.26 \pm 1.19^{a}$} \\
\hline
\end{tabular}

${ }^{a b}$ Means without a common superscript within row are significantly different $(p<0.01)$

In the PGF2 $\alpha 40$ group $80.00 \%(24 / 30)$ of the treated cows reacted. The cows were most likely to exhibit estrus between the $4^{\text {th }}$ and the $6^{\text {th }}$ day after treatment, when $40.00 \%(12 / 30)$ of the cows reacted, while $6.67 \%(2 / 30)$ reacted after 7 days or more. Estrous response in the PGF2 $\alpha 50$ group was registered in $86.67 \%$ of treated cows (26/30). In the first three days after treatment $40.00 \%$ $(12 / 30)$ of the cows entered into estrus, while $3.33 \%(1 / 30)$ reacted between the $7^{\text {th }}$ and the $9^{\text {th }}$ day, and $10.00 \%(3 / 30)$ after 10 days. Treatment with $\mathrm{GnRH}$ resulted in estrous response in $93.34 \%(28 / 30)$ of the treated cows. The largest number of cows $36.67 \%(11 / 30)$ reacted in the first three days, while only $6.67 \%(2 / 30)$ of the cows reacted after the $10^{\text {th }}$ day. In the control group a total of $63.34 \%(19 / 30)$ of the cows reacted. The greatest estrous response occurred after the $10^{\text {th }}$ day, when 
$33.33 \%$ of cows (10/30) reacted, while not a single cow reacted in the first three days. The durations of treatment - estrous response interval were $3.92 \pm 0.49$, $4.69 \pm 0.68,5.14 \pm 0.76$ and $11.26 \pm 1.19$, respectively. A statistically high significant difference was found between experimental and control groups $(p<0.01)$. The pregnancy rate and insemination index are shown in Table 2.

Table 2. Pregnancy rate and insemination index

\begin{tabular}{|l|c|c|c|c|c|c|c|}
\hline \multirow{2}{*}{ Groups } & \multicolumn{7}{|c|}{ Parameters } \\
\cline { 2 - 7 } & \multicolumn{2}{|c|}{$\begin{array}{c}\text { Number of } \\
\text { inseminated cows }\end{array}$} & \multicolumn{2}{|c|}{$\begin{array}{c}\text { Pregnancy rate at } \\
\text { first insemination }\end{array}$} & \multicolumn{2}{c|}{$\begin{array}{c}\text { Total pregnancy } \\
\text { rate }\end{array}$} & \multirow{2}{*}{$\begin{array}{c}\text { Insemination } \\
\text { index }\end{array}$} \\
\cline { 2 - 7 } & $\mathrm{n}$ & $\%$ & $\mathrm{n}$ & $\%$ & $\mathrm{n}$ & $\%$ & \\
\hline \hline $\mathrm{PGF}_{2 \alpha} 40$ & 23 & 95.83 & 16 & 69.56 & 18 & 78.26 & 1.12 \\
\hline $\mathrm{PGF}_{2 \alpha} 50$ & 24 & 92.30 & 18 & 75.00 & 20 & 83.33 & 1.11 \\
\hline GnRH & 26 & 92.86 & 17 & 65.38 & 19 & 73.08 & 1.12 \\
\hline Control & 16 & 84.21 & 7 & 43.75 & 13 & 81.25 & 1.86 \\
\hline
\end{tabular}

$a, b$ Means without a common superscript within column are significantly different $(p<0.05)$

The pregnancy rate of cows in PGF2 $\alpha 40$ at first insemination was $69.56 \%$ (16/23), and the total pregnancy rate was $78.26 \%$ (18/23). In the PGF2 $\alpha 50$ group the pregnancy rate at the first insemination was $75.00 \%(18 / 24)$, and the total pregnancy rate was $83.33 \%(20 / 24)$. Cows in the $\mathrm{GnRH}$ group achieved a pregnancy rate of $65.38 \%(17 / 26)$ at first insemination and a total pregnancy rate of $73.08 \%(19 / 26)$. In the control group the pregnancy rate achieved at the first insemination was $43.75 \%(7 / 16)$ and total pregnancy rate was $81.25 \%(13 / 16)$. No statistically significant $(p>0.05)$ difference was observed in pregnancy rates at first insemination and total pregnancy rates between the groups. Insemination indices by groups were $1.12,1.11,1.12$ and 1.86 , respectively. The duration of service period (in days) is shown in Table 3.

Table 3. Duration of service period

\begin{tabular}{|l|c|c|c|c|}
\hline Groups & $\begin{array}{c}\text { Mean } \pm \text { standard } \\
\text { error }\end{array}$ & Minimum & Maximum & $\begin{array}{c}\text { CV } \\
\%\end{array}$ \\
\hline \hline $\mathrm{PGF}_{2 \alpha} 40$ & $52.54 \pm 0.66^{\mathrm{A} \mathrm{a}}$ & 45 & 62 & 6.17 \\
\hline $\mathrm{PGF}_{2 \alpha} 50$ & $54.69 \pm 0.73^{\mathrm{Ab}}$ & 50 & 64 & 6.84 \\
\hline $\mathrm{GnRH}$ & $60.46 \pm 1.03^{\mathrm{B}}$ & 52 & 69 & 9.04 \\
\hline Control & $68.32 \pm 1.46^{\mathrm{C}}$ & 57 & 78 & 9.34 \\
\hline
\end{tabular}

$A, B$ Means without a common superscript within column are significantly different $(p<0.01)$

a, bMeans without a common superscript within column are significantly different $(p<0.05)$

The service period of cows in the PGF $2 \alpha 40$ group varied from 45 to 62 days, with an average value of $52.54 \pm 0.66$ days; in the PGF2 $\alpha 50$ group from 50 to 64 
Acta Veterinaria (Beograd), Vol. 62, No. 5-6, 591-598, 2012.

Mujić $\mathrm{E}$ et al.: Induction and synchronization of estrus in

dairy cows using a single injection of PGF $2 \alpha$ and GnRH

days, with an average value of $54.69 \pm 0.73$ days; in the GnRH group from 52 to 69 days, with an average value of $60.46 \pm 03.01$ days, and in the control group from 57 to 78 days, with an average value of $68.32 \pm 1.46$ days. The duration of the service period of cows in all experimental groups (40 PGF2 $\alpha$, PGF2 $\alpha 50, \mathrm{GnRH}$ ) was statistically different from cows in the control group $(p<0.01)$. A statistically significant difference $(p<0.05)$ was found between groups PGF2 $\alpha 40$ and PGF2 $\alpha$ 50 , while a statistically highly significant difference $(p<0.01)$ was observed between PGF2 $\alpha 40$ and GnRH, PGF2 $\alpha 50$ and GnRH.

\section{DISCUSSION}

The possibility that cows receive a single application of prostaglandins is dependent on the confirmation of the existence of corpus luteum. If the application of PGF2 $\alpha$ was performed during diestrus, luteolysis and estrus could be expected to occur 2-7 days after application. Treating cows in this way, Seguin (1980) reported that $34 \%$ of the cows entered into estrus on the third day and $32 \%$ on the fourth day. However, $2 \%$ of the cows came into estrus on the first day, $8 \%$ on the second day, $17 \%$ on the fifth day, $3 \%$ on the sixth day, and $4 \%$ on the seventh day. In our study, the estrous response in the PGF2 $\alpha 40$ group was $80.00 \%(24 / 30)$ and in group PGF2 $\alpha 5086.67 \%$ (26/30), where $73.34 \%$ (22/30) of cows in both groups entered into estrus within the first 6 days. These results were expected because PGF2 $\alpha$ regresses the corpus luteum and breaks the negative feedback of progesterone, and brings the cows into a new estrous cycle. It is not surprising that some of the cows treated with PGF2 $\alpha$ failed to respond, given the difficulties in distinguishing ovarian structures by rectal palpation in the period from the $5^{\text {th }}$ to the $7^{\text {th }}$ day relative to the period of extremely well-developed corpus luteum. Our results of estrous response are better than those of Amer (2008), who reported that $68.3 \%$ of Holstein cows exhibited estrus after the first treatment with prostaglandin and $71.7 \%$ after the second treatment. Positive experiences with the aim of inducing luteolysis after PGF2 $\alpha$ application are reported by Elmarimi et al. (1983), who significantly shortened the treatment-estrous response interval in Holstein and Jersey cows. In our study, treatment with $\mathrm{GnRH}$ resulted with estrous response of $93.34 \%(28 / 30)$. These results are in agreement with those of Benmrad and Stevenson (1986), who, by applying either PGF2 $\alpha$ or GnRH only, increased the estrous response and shortened the treatment-estrus interval in Holstein cows with normal and abnormal puerperium.

In reproduction management it is very important to establish a reliable system for timely detection of estrus, because otherwise extension of the service period may occur (Opsomer et al., 1996). The analysis of reproductive records of a large number of dairy farms showed that the percentage of detected estrus ranged from $48.3 \%$ (Kinsel and Etherington, 1998) to 71.0\% (Mayne et al., 2002). On the other hand, according to Rhodes et al. (2003), between 11 and $38 \%$ of cows in the first 50-60 days postpartum were anestrous, and the reasons for this state, as cited by researchers, include negative energy balance and the emergence of peripartum diseases. The estrous response of hormonally treated 
cows in our study was high. The reason for this lies in the fact that the genetic potential of cows is not fully utilized, and that cows are not forced to maximum milk production. Hormonal treatment was performed at the optimal time, physiological conditions for the establishment of synchronized estrus were present. The cows were healthy, of low parity structure, and in breeding condition. Free stall system with seasonal access to pasture, combined with a standardized diet, further contributed to the results of estrous response of analyzed cows.

Based on the analysis of reproductive records of a large number of dairy farms, conception at first insemination ranged from $37.1 \%$ (Mayne et al., 2002) to $40.7 \%$ (Galon et al., 2010), which is certainly an unsatisfactory result. The pregnancy rate in our study was above $70 \%$, which is considered satisfactory, but there was no statistically significant difference between control and experimental groups. The conception rate according to Amer (2008) after the first injection of prostaglandin was $56.3 \%$ and $50.0 \%$ after the second. Fallah and Ajami (2010) after two treatments with PGF2 $\alpha$ achieved a pregnancy rate of $81.48 \%$. Répási et al. (2005) reported a significantly higher pregnancy rate in cows that were treated twice with PGF2 $\alpha$. Benmrad and Stevenson (1986) reported that treatment only with PGF2 $\alpha$ or GnRH improves the fertility of dairy cows, especially those with puerperal problems, while Stevenson and Call (1988) concluded that the treatments in early postpartum did not improve reproductive performance. In our study the treatment was carried out in the final stage of puerperium, which had a favorable effect on fertility results. Application of PGF2 $\alpha$ can improve conception to a greater degree, but its application at an exactly defined time limits its use. However, it is not possible to give a clear recommendation for the use of PGF2 $\alpha$ for routine control of ovulation, because only cows with a mature corpus luteum will respond to a single application of PGF2 $\alpha$. Looking at the average value of the insemination index of cows in the experimental groups, we can conclude that it was better than that of Cilek and Tekin (2005), who reported a value of 1.76 after the expression of spontaneous estrus. The results obtained in experimental groups are do to the fact that the reproductive service on the farm is well organized, and following detection of estrus artificial insemination is carried out promptly, using semen of known origin and good quality.

In adequate conditions of accommodation, nutrition and care, Simmental breed cows achieve optimal service period of 60-90 days. This includes the time required for complete involution of genital organs. According to the findings of Pantelic et al. (2008), the average duration of the service period was 115.19 days, while a duration of 153.82 days was reported by Petrovic (2007). Slightly shorter duration of 93.87 days was reported by Cilek and Tekin (2005) and 94 days by Prandi et al. (1994). Generally, the results obtained in our study were significantly better. Also, in all experimental groups the service period was significantly shorter $(p<0.01)$ compared to the control group, which was one of the objectives of the study.

Estrous response, insemination index and duration of service period in our study were satisfactory. Examined hormonal treatments can be easily applied on small-scale farms. Hormone treatment causes a high estrous response, which facilitates the detection of estrus and timely insemination of cows. Also, we 
Acta Veterinaria (Beograd), Vol. 62, No. 5-6, 591-598, 2012.

Mujić $\mathrm{E}$ et al.: Induction and synchronization of estrus in

dairy cows using a single injection of PGF2 $\alpha$ and GnRH

achieved increased calving over a short period on an annual basis and a desired lactation period of 305 days. All the aforementioned improve reproductive efficiency and directly affect production efficiency.

\section{CONCLUSION}

Based on the obtained results, it can be concluded that the hormonal treatment used in this study achieved a satisfactory degree of estrous response and shortened the duration of the service period. The obtained results justify the application of this hormonal treatment in practical production, which together with the optimization of other production factors would improve reproductive performance on dairy farms and thus increase the efficiency of milk production.

Address for correspondence:

Emir Mujić, MSc

Biotechnical Faculty

Kulina bana 2, 77000 Bihać

Bosnia and Herzegovina

E-mail: mujic_emir@yahoo.com

\section{REFERENCES}

1. Amer HA, 2008, Oestrus synchronization in high lactating dairy cows, Mljekarstvo, 58, 33-46.

2. Benmrad M, Stevenson JS, 1986, Gonadotropin-releasing hormone and prostaglandin F2 alpha for postpartum dairy cows: estrous, ovulation, and fertility traits. J Dairy Sci, 69, 800-11.

3. Britt JH, Kittok R, Harrison DS, 1974, Ovulation, oestrus and endocrine response after GnRH in early postpartum cows, J Anim Sci, 39, 915-9.

4. Cilek S, Tekin ME, 2005, Environmental factors affecting milk yield and fertility traits of Simmental cows raised at the Kazova state farm and phenotypic correlations between these traits, Turk $J$ Vet Anim Sci, 29, 987-93.

5. Diskin MG, Mackey DR, Roche JF, Sreenan JM, 2003, Effects of nutrition and metabolic status on circulating hormones and ovarian follicle development in cattle, Anim Reprod Sci, 78, 345-70.

6. Dobson H, Smith RF, Royal MD, Knight CH, Sheldon IM, 2007, The high producing dairy cow and its reproductive performance, Reprod Domest Anim, 42(Suppl 2), 17-23.

7. Elmarimi AA, Gibson CD, Morrow D, Marteniuk J, Gerloff B, Melancon J, 1983, Use of prostaglandin $\mathrm{F} 2$ alpha in the treatment of unobserved estrus in lactating dairy cattle, Am J Vet Res, 44, 10814.

8. Fallah Rad AH, Ajam G, 2010, Comparison of Reproductive Parameters, Plasma and Milk E2 and P4 Concentrations Following Application of Ovsynch-CIDR vs. Two Consecutive Injections of PGF2 $\alpha$, in Dairy Holstein Cows, J Anim Vet Adv, 9, 144-8.

9. Galon N, Zeron Y, Ezra E, 2010, Factors affecting fertility of dairy cows in Israel, J Reprod Dev, 56 Suppl, 8-14.

10. García-Ispierto I, López-Gatius F, Santolaria P, Yániz JL, Nogareda C, López-Béjar M, 2007, Factors affecting the fertility of high producing dairy herds in northeastern Spain, Theriogenology, 67, 632-8.

11. Groehn YT, Rajala-Schultz PJ, 2000, Epidemiology of reproductive performance in dairy cows, Anim Reprod Sci, 60-61, 605-14.

12. Kinsel ML, Etherington WG, 1998, Factors affecting reproductive performance in Ontario dairy herds, Theriogenology, 50, 1221-38.

13. Lauderdale JW, Seguin BE, Stellflug JN, Chenault JR, Thatcher WW, Vincent CK, Loyancano AF, 1974, Fertility of cattle following PGF2 $\alpha$ injection, J Anim Sci, 38, 964-7. 
14. Lopez-Gatius F, 2003, Is fertility declining in dairy cattle? A retrospective study in northeastern Spain, Theriogenology, 60, 89-99.

15. Mayne CS, McCoy MA, Lennox SD, Mackey DR, Verner M, Catney DC et al., 2002, Fertility of dairy cows in Northern Ireland, Vet Rec, 150, 707-13.

16. Nakada $K, 2006$, How to improve reproductive efficacy from now in Japan? Find out the factors of late lactation to predict postpartum reproductive diseases, J Reprod Dev, 52, 177-83.

17. Opsomer G, Mijten P, Coryn M, De Kruif A, 1996, Post Partum Anestrous in Dairy Cows: A review, Vet Quart, 18, 68-75.

18. Pantelić V, Skalicki Z, Petrović MM, Aleksić S, Ostojić-Andrić D, Novaković Ž, 2008, The effect of breeding region on certain fertility parameters of Simmental cows, Biotech Anim Husbandry, 24, 1-8.

19. Petrie A, Watson $P, 2006$, Statistics for veterinary and animal science, Blackwell publishing.

20. Petrovic MD, Skalicki Z, Bogdanovic V, Petrovic MM, 2007, The effect of paragenetic factors on reproductive traits of Simmental cows, Biotech Anim Husbandry, 23, 1-8.

21. Prandi A, Motta M, Tondolo A, Rossi C, 1994, Evaluation of the reproductive efficiency of Simmental and Friesian dairy cows farmed in Friuli (Northeast Italy) by the analysis of progesterone levels, Theriogenology, 42, 65-78.

22. Répási A, Beckers JF, Sulon J, Karen A, Reiczigel J, Szenci O, 2005, Effect of the type and number of prostaglandin treatments on corpus luteum, the largest follicle and progesterone concentration in dairy cows, Reprod Domest Anim, 40, 436-342.

23. Rhodes FM, McDougall S, Burke CR, Verkerk GA, Macmillan KL, 2003, Treatment of cows with an extended postpartum anestrous interval. J Dairy Sci, 86, 1876-94.

24. Seguin $B, 1980$, Altering estrous cycles in cows by intrauterine infusion, In: Morrow DA editor, Current therapy in theriogenology, Philadelphia: WB Saunders, 177-88.

25. Stevenson JS, Call EP, 1988, Fertility of postpartum dairy cows after administration of gonadotropinreleasing hormone and prostaglandin F2 alpha: a field trial, J Dairy Sci, 71, 1926-33.

\title{
PRIMJENA JEDNOKRATNE INJEKCIJE PGF $2 \alpha$ I GRRH U SVRHU INDUKCIJE I SINHRONIZACIJE ESTRUSA KOD MLIJEČNIH KRAVA
}

\author{
MUJIĆ E, JOTANOVIĆ STOJA, NEDIĆ D, TEŠIĆ M, ŠAHINOVIĆ R, VEKIĆ M i VILIĆ H
}

\section{SADRŽAJ}

Cilj ovog rada bio je da se ispita uticaj tretmana sa $\mathrm{PGF}_{2 \alpha}$ i GnRH na estrusno reagovanje, fertilitet i trajanje servis-perioda krava simentalske rase u laktaciji. Ukupno 120 krava bilo je podijeljeno u četiri grupe po 30 krava: prva grupa $\left(\mathrm{PGF}_{2 \alpha} 40\right)$ je tretirana 40 dana post partum sa jednom injekcijom $2 \mathrm{ml}$ analoga prostaglandina (Estrumate), dok je druga grupa $\left(\mathrm{PGF}_{2 \alpha} 50\right)$ tretirana na isti način 50 dana, treća grupa $(\mathrm{GnRH})$ tretirana je 40 dana post partum sa jednom injekcijom $2 \mathrm{ml} \mathrm{GnRH}$ analoga (Receptal), a četvrta grupa nije hormonalno tretirana. Fertilitet krava nije se statistički značajno razlikovao između grupa $(p>0.05)$, dok je kod estrusnog reagovanja krava i dužine trajanja servis-perioda između oglednih grupa i kontrolne grupe ustanovljena statistički značajna razlika $(p<0.01)$. 